\title{
Konferencja „Polsko-rumuńskie związki historyczne i kulturowe" w Suczawie
}

$\mathrm{W}$ dniach 6-8 września 2012 r. już po raz czternasty odbyły się Dni Polskie w Suczawie (Rumunia). Impreza ta jest organizowana przez bardzo prężnie działający Związek Polaków w Rumunii. W wydarzeniu wzięli udział przedstawiciele Senatu i Sejmu Rzeczypospolitej Polskiej, a także przedstawiciele parlamentu Rumunii oraz rumuńskich władz państwowych i samorządowych. Obecny był również ambasador RP w Rumunii, Marek Szczygieł, który odczytał list Prezydenta Rzeczypospolitej Bronisława Komorowskiego adresowany do uczestników spotkania. Częścią Dni Polskich, jak co roku, było międzynarodowe sympozjum naukowe. Tym razem zatytułowano je: ,Polsko-rumuńskie związki historyczne i kulturowe". Podczas obrad referaty wygłosiło ponad 40 naukowców - historyków, socjologów, filologów i politologów. Konferowano w trzech sekcjach: „W kręgu historii”, „W kręgu problematyki mniejszości narodowych” oraz „W kręgu kultury i literatury”.

Najliczniejsza była sekcja historyczna. Zainicjował ją ogólny referat dr. Mirosława Karapyty, marszałka województwa podkarpackiego, przedstawiający zarys stosunków polsko-rumuńskich w latach 1945-1965. Następnie głos zabierali referenci reprezentujący ośrodki naukowe z Rumunii, Polski, Mołdawii i Włoch. Prof. Ilona Czamańska z Poznania mówiła o aspekcie polskim w społeczności wołoskiej. O polskich i mołdawskich osobliwościach numizmatycznych w kolekcji Muzeum Bukowiny w Suczawie opowiedziała dr Monica Dejan. Prof. Aleksander Smoliński z Uniwersytetu Mikołaja Kopernika w Toruniu omówił niedoszłe próby zamachu na rumuńską parę królewską podczas jej wizyty w Polsce w 1923 roku, a prof. 
Krzysztof Filipow z Uniwersytetu w Białymstoku przedstawił rumuńskich kawalerów Orderu Virtuti Militari z lat 1919-1939. W tej sekcji referaty wygłosili także prof. Constantin Rezachevici z Bukaresztu (,Średniowieczne stosunki polsko-rumuńskie na nieznanych w Rumunii polskich obrazach"), dr Lilia Zabolotnaia z Kiszyniowa (,Zagraniczni podróżnicy o katolickiej ludności z rejonowych miast w XVII w.”), dr Veniamin Ciobanu z Jass („Internacjonalizacja «kwestii ukraińskiej» i Europa Południowo-Wschodnia"), dr Florin Pintescu z Uniwersytetu Stefana Wielkiego w Suczawie („Uwagi dotyczące kampanii Jerzego Rakoczego II w Polsce w 1657 r.”), Michał Wasiucionek reprezentujący Departament Historii i Cywilizacji we Florencji („Wołoscy poddani jako polscy jeńcy”), dr Alina Felea z Kiszyniowa („Kilka aspektów bukowińskiej wypowiedzi testamentowej z XVIII i początków XIX w.”), dr Hanna Szczechowicz z Włocławka („Podstawy polsko-rumuńskich relacji handlowych w myśl konwencji z 1921 r.”), dr Agnieszka Kastory z Uniwersytetu Jagiellońskiego („Polska i Rumunia przed Stałym Trybunałem Sprawiedliwości Międzynarodowej w sporach dotyczących żeglugi śródlądowej”), dr Daniel Hrenciuc („Podróże marszałka Józefa Piłsudskiego do Rumunii”), płk prof. Eugen Ichim z Bukaresztu („Generał Henri Cihoski”), dr Piotr Gołdyn z Konina („Wizyta ministra oświaty Rumunii Constantina Angelescu w Polsce w 1937 r. w świetle ówczesnych doniesień prasowych”), dr Krzysztof Spruch z Częstochowy („Polskie mienie wojskowe przejęte przez Rumunię we wrześniu 1939 r.”), dr Ion Constantin z Bukaresztu („Uwagi dotyczące podobieństw i różnic między komunizmem w Polsce i w Rumunii”), dr Maria Radziszewska z Uniwersytetu Warmińsko-Mazurskiego w Olsztynie („IV Światowy Festiwal Młodzieży Demokratycznej w Bukareszcie na łamach «Sztandaru Młodych» 1953”), ks. Jarosław Wąsowicz z Piły („Przemiany polityczne w Rumunii w latach 1989-1990 w świetle prasy solidarnościowej i drugiego obiegu”), dr Grzegorz Bonusiak z Rzeszowa („Stosunki gospodarcze Polski i Rumunii w latach 1990-2006”), dr Bartłomiej Zdaniuk z Uniwersytetu Warszawskiego („Czynniki gwarantujące trwałość systemu politycznego Polski, Rumunii i Republiki Mołdawii”).

Jako że Bukowina to region wieloetniczny, bardzo interesujące były obrady sekcji poświęconej problematyce mniejszości narodowych. Zainicjował je referat dr. hab. Krzysztofa Zajasa z Uniwersytetu Jagiellońskiego, zatytułowany „Pograniczna tożsamość niemożliwa”. Kolejne trzy referaty dotyczyły kwestii językoznawczych. Wygłosiły je: prof. Anna Zielińska z Warszawy (,Język polski na Bukowinie w kontekście badań nad polszczy- 
zną kresową”), dr Helena Krasowska z Warszawy („Mniejszość rumuńska na ukraińskiej Bukowinie: sytuacja językowa”) i Karina Stempel-Gancarczyk z Wolbromia (,Wybrane problemy logopedyczne w nauczaniu języka polskiego jako obcego w środowisku rumuńskojęzycznym"). W ramach omawianej sekcji referaty przygotowali również: dr Jan Bujak z Krakowa (,Rola Towarzystwa Szkoły Ludowej w odrodzeniu i utrwaleniu polskości bukowińskich Polaków”), Natalia Ogan z Opola („Obchody rocznic narodowościowych i ważnych wydarzeń na Bukowinie na początku XX w.”), dr hab. Jan Nowak z Uniwersytetu Śląskiego w Katowicach (,Zapomniane wspomnienia Polaków o Rumunii”), Adam Rossmanith z Krakowa („Procesy migracji w wybranych skupiskach ludności polskiej na Bukowinie po 1989 r.”), doc. Nataliya Minyenkova z Doniecka („Polacy jako mniejszość narodowa na Donbasie: życie polityczne, socjalne, kulturalne"), oraz dr Ewa Kocój i Paweł Lechowski z Krakowa (,Zapomniane dziedzictwo kulturowe, czyli profesje cygańskie w Polsce i Rumunii”).

Nie mniej ciekawe były referaty wygłoszone w ramach sekcji poświęconej problematyce kultury i literatury. Jako pierwsza wystapiła dr Ewa Kocój z Uniwersytetu Jagiellońskiego, która omówiła kanoniczną i ludową symbolikę dni tygodnia w rumuńskim kalendarzu prawosławnym. Dr Olimpia Mitric z Suczawy przedstawiła polskie książki w kolekcjach Biblioteki im. V. A. Urechia w Galati, natomiast dr Maria Loyola Opiela z Lublina zajęła się śladami myśli pedagogicznej bł. Edmunda Bojanowskiego na Bukowinie realizowanej przez Siostry Służebniczki BDNP. Dr Maciej Krotofil z Uniwersytetu Mikołaja Kopernika w swoim referacie zajął się wątkami biografii Augusty Kochanowskiej - bukowińskiej artystki malarki, która ostatnie lata swojego życia spędziła w Toruniu. Następnie głos zabrali: dr Adam Gałkowski z Warszawy („Ciprian Porumbescu - Cyprian Gołębiowski 1853-1883. Rumuński muzyk z polskimi korzeniami”), Vasile I. Schipor („Iraclie Golembiowski-Porumbescu 1823-1896, «światły apostoł» Bukowiny XIX w.”), Anna Dzidzic z Katowic (,Rumunia i Bukowina w twórczości Stanisława Vincenza"), dr Gabriela Gavril-Antonesei z Jass („Bruno Schulz i Sanatorium pod Klepsydrq - uwagi na temat thumaczenia i egzegezy"), dr hab. Jarosław Fazan z Uniwersytetu Jagiellońskiego (,Rumunia na szlaku Andrzeja Stasiuka”), dr Constantin Geambasu z Bukaresztu („Czesław Miłosz w Rumunii”) oraz dr Anna Oczko z Krakowa (,Rumuńskie echo w polskich górach - nazwy szczytów i gór pochodzenia rumuńskiego"). 
Wygłoszone referaty spotkały się z dużym zainteresowaniem słuchaczy i wzbudziły ciekawą dyskusję. Ze względu na ich wielką wartość naukową zostaną opublikowane w kolejnym tomie pokonferencyjnym, który - podobnie jak poprzednio - zostanie zaprezentowany na najbliższej konferencji w Suczawie.

Podsumowanie obrad sympozjum zostało połączone z promocją wydawnictw poświęconych problematyce polsko-rumuńskiej. Zaprezentowano też tom zawierający publikowane efekty konferencji z $2011 \mathrm{r}$.

Uczestnicy Dni Polskich i sympozjum wzięli także udział w licznych wydarzeniach kulturalnych oraz zostali zaproszeni na polonijne dożynki zorganizowane we wsi Nowy Sołoniec, jednej z trzech wsi na rumuńskiej Bukowinie zamieszkanych $\mathrm{w}$ większości przez przedstawicieli mniejszości polskiej.

Maciej Krotofil

DOI: http://dx.doi.org/10.12775/EO.2012.015

\section{Konferencja naukowa ,Śląsk a I wojna światowa. Znaczenie regionu w czasie wojny i wpływ wojny na sytuację lokalną"}

W $\begin{aligned} & \text { uzeum Śląskie w Katowicach zorganizowało } 28 \text { listopada } 2012 \text { r. kon- } \\ & \text { ferencję naukową pt. „Śląsk a I wojna światowa. Znaczenie regionu }\end{aligned}$ w czasie wojny i wpływ wojny na sytuację lokalną". Mimo regionalnego charakteru tematyki sympozjum swoje referaty wygłosili badacze nie tylko reprezentujący ośrodki śląskie, ale także wywodzący się z Krakowa, Łodzi czy Torunia.

W zamyśle organizatorów listopadowa konferencja miała być kolejną już częścią cyklu naukowych spotkań i dyskusji dotyczących szeroko pojętej I wojny światowej. Pierwsza z nich odbyła się w listopadzie $2011 \mathrm{r}$., również pod tytułem „Śląsk a I wojna światowa”. Organizatorzy postawili sobie wówczas za cel uzyskanie odpowiedzi na pytanie, jaką rolę odgrywał Śląsk w I wojnie światowej, a także o to, jak wydarzenia polityczne, gospodarcze i militarne wpływały na sytuację na Śląsku ${ }^{1}$ Trzecie sympozjum

Zob. http://www.muzeumslaskie.pl/edukacja-konferencje-slask-a-i-wojna-swiatowa. php [dostęp: 11 lutego 2013]. 